\title{
Habilidades de memória de trabalho e o grau de severidade do desvio fonológico $* * * *$
}

\section{Working memory abilities and the severity of phonological disorders}

\author{
Lisiane Zorzella Linassi* (llinassi@ terra.com.br) \\ Marcia Keske-Soares** \\ Helena Bolli Mota***
}

\section{*Fonoaudióloga. Mestre em Distúrbios da Comunicação Humana pela Universidade Federal de Santa Maria (UFSM).}

**Fonoaudióloga. Doutora em Lingüística Aplicada pela Pontifícia Universidade Católica do Rio Grande do Sul (PUCRS). Professora do Curso de Graduação em Fonoaudiologia, Especialização em Linguagem Mestrado em Distúrbios da Comunicação Humana da UFSM.

***Fonoaudióloga. Doutora em Lingüística Aplicada pela PUCRS. Professora do Curso de Graduação em Fonoaudiologia, Especialização em Linguagem e Mestrado em Distúrbios da Comunicação Humana da UFSM.

*****Artigo Extraído da Dissertação de Mestrado apresentada ao Curso de Mestrado em Distúrbios da Comunicação Humana da UFSM (Linassi, 2002).

Artigo de Pesquisa

Artigo Submetido a Avaliação por Pares

Conflito de Interesse: não

Recebido em 30.09.2003. Revisado em 8.01.2004; 10.05.2004; 9.02.2004; 24.08.2004; 16.12.2004; 11.11.2005.

Aceito para Publicação em 11.11.2005.

\section{Abstract}

Background: working memory. Aim: to verify the performance of working memory abilities and their relation with the severity of phonological disorders. Method: 45 children, with ages between 5.0 and 7.11 years, with evolutional phonological disorders (EFD), 17 female and 18 male, were evaluated. All subjects were assessed using the Child Phonological Evaluation proposed by Yavas et al. (1991). The severity of the disorder was determined by the Percentage of Correct Consonants (PCC) proposed by Shriberg and Kwiatkowski (1982), classifying the phonological disorder as severe, moderate-severe, average-moderate and average. After that, subtest 5 of the Psycholinguistic Abilities Test (ITPA - Bogossian \& Santos, 1977) and the non-word repetition test (Kessler, 1997) were applied. Results: after analyzing the data according the statistical tests of Kruskal Wallis and Duncan, it was verified that the performance of moderate-severe and severe individuals in the non-word repetition test was inferior to that of averagemoderate and average individuals. However, performance results in the digit repetition test did not present a positive correlation with severity. Conclusion: the performance of phonological memory has a relation with the severity of phonological disorders. This allows us to accept the idea that the phonologic memory is related to speech production. Regarding the central executor, the results indicate that the performance in digit repetition, used to assess the central executor, did not present a correlation with the severity of the disorder. This can be justified by the fact that the central executor is more directly related to vocabulary acquisition and is responsible for processing and storing information.

Key Words: Memory; Articulation Disorders; Child Language.

\section{Resumo}

Tema: memória de trabalho. Objetivo: verificar o desempenho das habilidades de memória de trabalho e sua relação com o grau de severidade do desvio fonológico. Método: foram avaliadas 45 crianças com desvio fonológico evolutivo (DFE), com idades entre 5:0 a 7:11, sendo que 17 eram do sexo feminino e 18 do masculino. Todos os sujeitos foram avaliados utilizando-se a Avaliação Fonológica da Criança proposta por Yavas et al. (1991). O grau de severidade do desvio estabelecido por Shriberg e Kwiatkowski (1982), foi determinado pelo cálculo do Percentual de Consoantes Corretas (PCC), o qual foi utilizado para classificar o desvio fonológico em severo, moderado-severo, médio-moderado e médio. A seguir, foi aplicado o subteste 5 do ITPA (Bogossian e Santos, 1977) e o teste de repetição de palavras sem significado (Kessler, 1997). Resultados: verificou-se ao aplicar o teste estatístico Kruskal Wallis e o teste de Duncan, que o desempenho na repetição de palavras sem significado no grau moderado-severo e no grau severo foi inferior ao desempenho no desvio médio-moderado e médio, mas o desempenho na repetição de seqüência de dígitos não apresentou relação positiva com o grau de severidade do desvio. Conclusão: o desempenho da memória fonológica apresenta relação positiva com o grau de severidade do desvio fonológico. Isso permite aceitar a idéia, de que a memória fonológica está relacionada com a produção da fala. Com relação ao executivo central, os resultados permitem concluir, que o desempenho na repetição de seqüência de dígitos, que vem sendo utilizado para avaliar o executivo central, não teve relação com o grau de severidade do desvio. Pode-se justificar estes resultados, pelo fato de o executivo central estar mais relacionado com a aquisição do vocabulário e ser responsável pelo processamento e armazenamento de informações.

Palavras-Chave: Memória; Desvio Fonológico; Linguagem Infantil. 


\section{Introduction}

The knowledge of alterations that occur in the abilities of working memory and its relation with the severity degree of the phonological disorder is important to line up the process origins of alterations that occur in speech development.

The working memory, according to Flavell et al. (1999), is responsible for the temporary storing of information and has an active role in information processing.

Sternberg (2000) claims that the basic operations of memory are codification, storing and recuperation. The codification is the transformation of sensorial data entrance in a form of mental representation that can be stored. The storing is the conservation of the codified information. And the recuperation refers to the access and the usage of the stored information. All these processes interact and are interdependent.

Baddeley and Hitch (1974) consider working memory a short time memory system which is evolved in the temporary process and in the information storage. The working memory is characterized by a system of limited capacity, responsible for storing shortly the information in a phonological code.

The authors identified three components of working memory: the central executor, the phonological sketchpad and the visuo-spatial sketchpad. The authors say that the central executor is used when deal with tasks of higher cognitive demand, filling several functions, among them, the information flux regulation, the process and storage of information and the feeding of the information entrance into the phonological and the visuo-spacial sketchpad. The central executor can be assessed by repetition tests of digit span. The phonological sketchpad maintains the information codified verbally, and the visuo-spatial sketchpad is evolved in the process and maintenance of visuo and spatial information.

The phonological sketchpad has two components: the phonological storing, which turns the verbal material into phonological code (that deteriorates with time) and the rehearsing process, which refreshes the deteriorated representations in the phonological storage, keeping them in memory.

Baddeley (2001); Gathercole and Pickering (2000); Pickering et.al. (1999) mentioned that the working memory can be divided into components, which get damaged in the performance of some tasks in opposition to a normal performance in others are pointed out as an evidence of different components existence of working memory.

Some children older than four years old presents alteration in the normal speech development in different degrees, sometimes making it unintelligible. In this case, they are children who present phonological disorders. The problem of the phonological disorder goes beyond only an articulatory difficulty but an alteration in the phonological system organization.

Lamprecht (1999) claims that the Evolutional Phonological Disorder (EPD) receives this name because it is the deviance of a conduct line, of rules; once it evolves one of the most important of the linguistic components, the phonological degree and because it affects the linguistic development of the child, but not the motor, physical/or mental.

The severity degree of the disorder established by Shriberg and Kwiatkowski (1982) is determined by calculating the Percentage of Correct Consonants (PCC), which is widely used in Literature to classify the phonological disorder into severe, moderate-severe, medium-moderate and medium. Other classifications regarding the phonological disorder severity are described including evolving studies with Portuguese speakers. However, studies regarding the relation between the abilities of the working memory and the severity degree of the phonological disorder are unknown.

It is useful to remember that the working memory has an important role in vocabulary acquisition during the childhood. It is fundamental in the acquisition of language and in the speech development of children.

Adams and Gathercole (1995) mentioned that there is a meaningful link among the phonological memory, the speech production complexity and the choice of phonemes for the word production. The mistakes that occur in phonemes production are influenced by the acoustic characteristics; therefore, the similar phonemes are easily replaced. Thus, it can be helpful to know the relation between working memory and phonological disorder in order to understand the alterations that occur in the speech development.

The same authors pointed out that there is an intimate relation between the memory and the language production in terms of quantity and quality of the spontaneous speech produced by children. The children with phonological alteration in the linguistic development present severe choice. 
alterations in the work of the phonological memory. The place of the memory deteriorization seems to be in the storing component of the phonological memory. The process in which the verbal material is phonologically codified can be damaged in these children, so that the phonological representations are not sufficiently discriminated. It shows that alterations in the phonological memory can indirectly retard all the aspects of language development.

In a later study, Adams and Gathercole (2000) mentioned that the phonological memory and the development of the expressive language can have questions referring to the speech plan, instead specific factors of articulatory control. It means that alterations in the phonological memory can influence the sounds organization of the speech and not the phonemes articulations.

Regarding the effect of words extension, it is known that the size of the words influences the information storage, once the longer is the word (longer in syllables number and letters), the more difficult its storage will be. Baddeley and Hitch (1974) commented that the words extension can vary in quantity of letters, phonemes or syllables. Couture and McCauley (2000) claimed that longer words are harder to be repeated by children with language alteration, reflecting a limited capacity of phonological memory. The children with EFD are sensitive to the effect of words extension, presenting inferior performance of memory for lists of words and can have associated problems in phonological memory.

Santos and Siqueira (2002) refer that the phonological memory is often assessed by words extension tasks and logatomos. The authors refer that the retention of verbal information in the working memory is essential for sentence understanding - spoken and written - and for conducting words items.

It is important to say that nonsense words repetition tests assess more precisely the phonological memory because the input is unknown and it is not influenced by lexical influences (for example, phonological, semantic, syntax knowledge). In this case, the child will have to use the word representation without any meaning in memory to support its repetition (Gathercole et.al., 1999).

Gonçalves (2002) mentions that there are evidences about the interference of phonological memory in the learning of new words, in more elaborated grammatical constructions and in the language understanding, motivating them to rethink the cases and clinic conducts in the rehabilitation process of children with evolutional phonological disorders or with specific deficit in language. The author says that the clinic should consider the cognitive function of the memory, specifically the phonological one, in the moment of the assessment, the diagnosis and the therapeutic plan of children with specific deficit of language and evolutional phonological disorders.

Bull et al. (1999) refer that the central executor compounding the working memory is related to the vocabulary acquisition. Bishop et. al. (1999) refer that phonological memory alterations have been associated to phonological disorders in specific alterations of the language.

Jeronymo and Galera (2000) investigated the correlation between the abilities of language and phonological memory in preschool and first grade children. The authors believe that the initial difficulties of the phonological memory can contribute for future difficulties in language.

Macbride-Chang and Ho (2000) found relation among the phonological memory, the speech perception and the vocabulary development in preschool children. Oakhill and Kyle (2000) refer that the working memory is a determinant factor in task performance of sound categorization.

Having in mind the importance of the working memory for the linguistic development and in order to study the relation between the working memory and the phonological disorder, this study aimed to verify whether there is relation between the abilities of working memory and the severity degree of the phonological disorder.

\section{Method}

This research obtained the approval of the Ethic Committee in Research, at Center of Health Sciences of Federal University of Santa Maria (UFSM). This research project is properly registered on number 034/01.

Parents and/or tutors should authorize the children participation in the research by signing the clear and consent term.

To include subjects in the samples, the following criteria were established: to present evolutional phonological disorder diagnostic; not to present history of school level repetition; not to present hearing, psychological or neurological alterations suspect; not to present learning difficulty; to be approved at the phonoaudiologic choice in regard to language, oral motricity and child hearing process choice. 
The sample was composed by 45 children with evolutional phonological disorder (EPD), aged from 5:0 to 7:11, average age 6 years old , $27(60 \%)$ female and 18 (40) male. Children were chosen from preschool and first grade groups, from public schools in Santa Maria-RS, and some of them were included in the waiting list of Serviço de Atendimento Fonoaudiológico (SAF) of Federal University of Santa Maria (UFSM).

The phonological choice was performed with each child by the same examinator, in the school environment or at SAF, including: speech, language, hearing process, and sensor-motor-oral system.

The choice of speech was performed using the picture "room" from Child Phonological Assessment (Yavas, Hernandorena \& Lamprecht, 1991). With this picture understanding and expressing language was also assessed informally through spontaneous speech, in conversation with the children, requiring that they talked about the picture and told everyday facts. It was assessed the suitable answers, simple and complex requirements executor, logical organization of the thought, grammatical structures of the sentences, and the vocabulary used. The aim of this assessment was to confirm that the language alterations in these subjects were restricted to the phonological degree.

In the choice, the sensor-motor-oral system was assessed to discharge the presence of organic factors that would affect the production of speech sounds. The simplified assessment of the central hearing process was performed in order to assess the hearing abilities of sound localization, sequential hearing memory for verbal and non verbal sounds and cochlea palpebral reflex test for agogô.

Children with suspect of other alterations as hearing disorder, neurological and psychological alteration were sent to complementary exams (otorrinolaringological, audiological, neurological and psychological ones) and previously excluded from the sample.

The subjects with diagnosis of EPD were submitted to a complete phonological assessment, and later PCC analysis. Afterwards, assessment of two components of working memory was performed: central executor and phonological memory.

The visuo-spatial sketchpad process, the visual and spatial information storage and the verbal material will be codified in an image form. This component of the working memory has not been studied once there are few studies showing that it interferes meaningfully in language development.

The collection of speech samples of children with EPD was performed using an instrument proposed by Yavas, Hernandorena \& Lamprecht (1991). This assessment is performed through the naming and the spontaneous speech and elicits all the contrastive phonemes in all the positions they can occur regarding the syllable and word structure, obtaining a representative sample of our language sounds.

Through phonetic transcription and contrastive analysis of speech data, a determined severity degree of EPD was determined by calculating the Percentual of Correct Consonants (PCC), proposed by Shriberg and Kwiatkowski (1982). PCC was obtained from the division of the number of correct consonants (NCC) by the number of the correct consonants (NCC) plus the number of incorrect ones $(\mathrm{NCI})$, multiplied by a hundred, $(\mathrm{PCC}=[\mathrm{NCC} /$ $(\mathrm{NCC}+\mathrm{NCI})] \mathrm{x} 100)$.

According to the PCC results, the deviance levels determined by the authors were shared into: severe $(\mathrm{PCC}<50 \%)$, moderate-severe $(\mathrm{PCC}=51$ to $65 \%)$, medium-moderate $(\mathrm{PCC}=66$ to $85 \%)$ and medium $(\mathrm{PCC}=86$ to $100 \%)$.

The abilities assessment of the working memory was performed in two of its components - the central executor and the phonological memory -, based on Baddeley and Hitch Working Memory Model (1974).

The central assessment executor of the working memory was performed through the subtest 5 of Sequential Hearing Memory of Illinois Test of Psycholinguistic Abilities (ITPA), with Bogossian and Santos Brazilian Adaptation (1977). This test was used because it is the one which has been used recently in national and international studies (Kessler, 1997; Linassi et al. 2004), and it presents values of standardized analysis (Scale score 36 ) for the age used in this study.

This subtest consists on the immediate repetition of digit span that is from two to seven digits, totaling twenty eight, as presented out of sequence. As a procedure, children were told to repeat them in longer and longer sequences.

Children could try twice in every digit span, in case of first time failure. Only when the child repeated properly the digit span presented in one of the tries, it was considered right. When there were two wrong consecutive items, in both tries, the subtest application was ended.

To obtain the Gross Score, the criteria recommended by Bogossian and Santos was used 
(1977), counting two points to each right item in the first try, one point to each right item in the second one, and none to the wrong items in both. Once the Gross Score was obtained, the results were turned into Scalar Score, according to the ITPA instructions. According to ITPA, the Scalar Score expected for the studied age is thirty six points, considering six over or six above it, reaching an average between thirty and forty two points.

The assessment of phonological memory was performed from the Nonsense Word Repetition Test, elaborated by Kessler (1997). The test consists on the repetition of thirty nonsense words, organized in six lists, each with five of these words which may vary in syllable number, from one to six, constituted by simple syllable structure, privileging consonant-vowel and consonant-vowelconsonant ones.

The procedure of test performance consisted on presenting all the items from the six lists, one after the other. The child sitting next to the examinator should listen to each item, try to repeat it immediately like the examinator had said.

In this task, the repetition was considered correct when the child was able to repeat the item such as it was presented or when replaced some phoneme or syllable in words that are normally replaced in spontaneous speech, as verified by the Child Phonological Assessment. When the child presented changes and omissions of phonemes and syllables in the repetition of nonsense words that normally did not perform in spontaneous speech, it was considered incorrect.

The analysis of the answers was performed and the list with the highest number of syllables, in which there was correct repetition of the five items was considered. This was the criteria to determine the performance of sample children in the ability of the phonological memory.

In the end, the results were analyzed according to the different degrees of severity of the disorder to the repetition test of digit span and to the repetition test of nonsense words, verified through the Scalar Score.

After performing all the assessments, the data were grouped and turned in a table, two graphs and a picture. For the statistical analysis, KruskalWallis statistical test and the Variance Analysis through Duncan Test, both to the significance level of $\mathrm{p}>0,05$ (Siegel, 1975) were used.

\section{Results}

In the result analysis, regarding the severity degree of the phonological disorder, it was calculated the average and the standard deviance for the answers obtained in the digit span repetition, verified through the Scalar Score and, for the answers obtained in the nonsense words repetition, what can be seen in Table I.

TABLE 1. Values obtained in the repetition test of digit span and nonsense words, regarding the severity degree of the evolutional phonological disorder.

\begin{tabular}{|c|c|c|c|c|c|c|}
\hline \multirow[t]{2}{*}{ Provas } & Grau de Severidade & $\mathrm{N}$ & Média** & Desvio Padrão & Mínimo & Máximo \\
\hline & Médio & 10 & $29,300^{\mathrm{a}}$ & 2,9078 & 23,000 & 33,000 \\
\hline escores* & médio moderado & 18 & $28,105^{\mathrm{a}}$ & 2,8847 & 23,000 & 36,000 \\
\hline \multirow[t]{3}{*}{ escalar } & moderado/severo & 10 & $28,800^{\mathrm{a}}$ & 2,5298 & 26,000 & 34,000 \\
\hline & severo & 7 & $28,714^{\mathrm{a}}$ & 2,6904 & 25,000 & 32,000 \\
\hline & médio & 10 & $3,600^{\mathrm{a}}$ & 0,8433 & 2,000 & 5,000 \\
\hline número & médio moderado & 18 & $3,421^{\mathrm{ab}}$ & 0,6924 & 2,000 & 4,000 \\
\hline \multirow[t]{2}{*}{ sílabas* } & moderado/severo & 10 & $2,800^{\mathrm{bc}}$ & 0,9189 & 2,000 & 4,000 \\
\hline & severo & 7 & $2,286^{\mathrm{c}}$ & 0,7559 & 1,000 & 3,000 \\
\hline
\end{tabular}

\footnotetext{
* Não existe diferença significante $(\mathrm{p}>0,05)$ - Teste de Kruskal-Wallis.

** Letras iguais não diferem estatisticamente.
} 
Picture 1 shows the results obtained in the Scalar Score for the different levels of phonological disorder severity.

Picture 2 shows the results obtained in the repetition of nonsense words for the different degrees of severity of the phonological disorder.
Picture 3 shows the comparison of the results obtained in the repetition test of nonsense words regarding the severity degree of the phonological disorder.

PICTURE 1. Values obtained in Score Scalar regarding the severity degree of the phonological disorder.

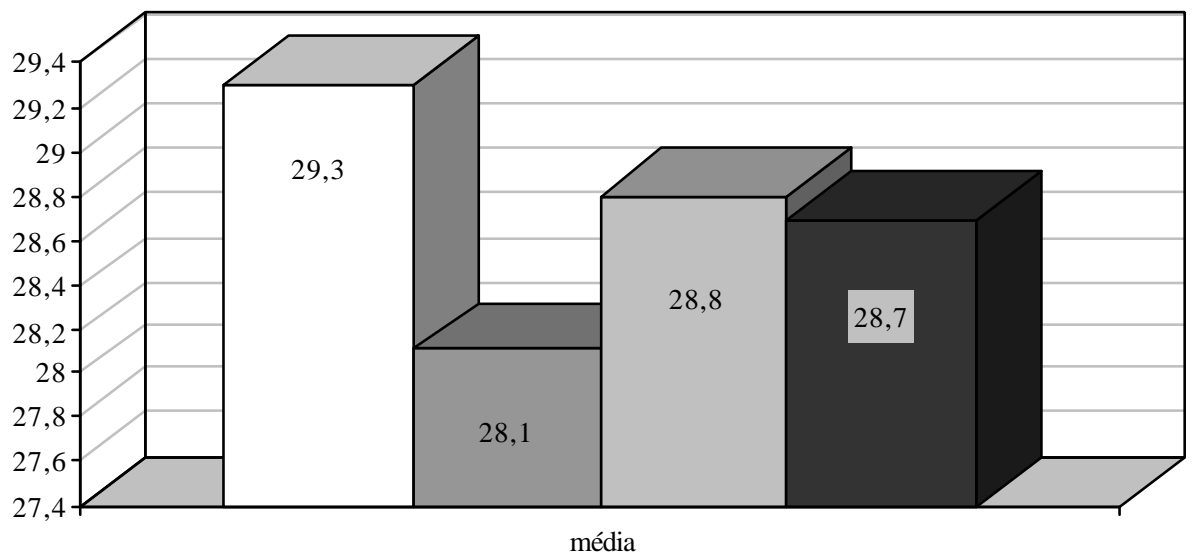

$\square$ médio $\square$ médio/moderado $\square$ moderado/severo $\square$ severo

PICTURE 2. Values obtained in the repetition test of nonsense words regarding the severity degree of the phonological disorder.

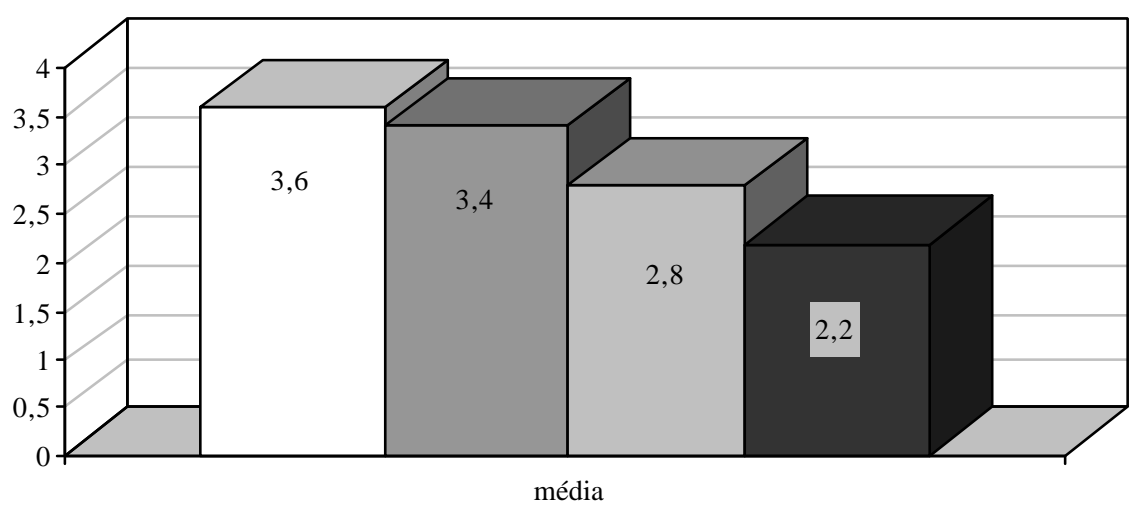

$\square$ médio $\square$ médio/moderado $\square$ moderado/severo $\square$ severo 
PICTURE 3. Comparison of results obtained in the repetition test of nonsense words regarding the severity degree of the phonological disorder.

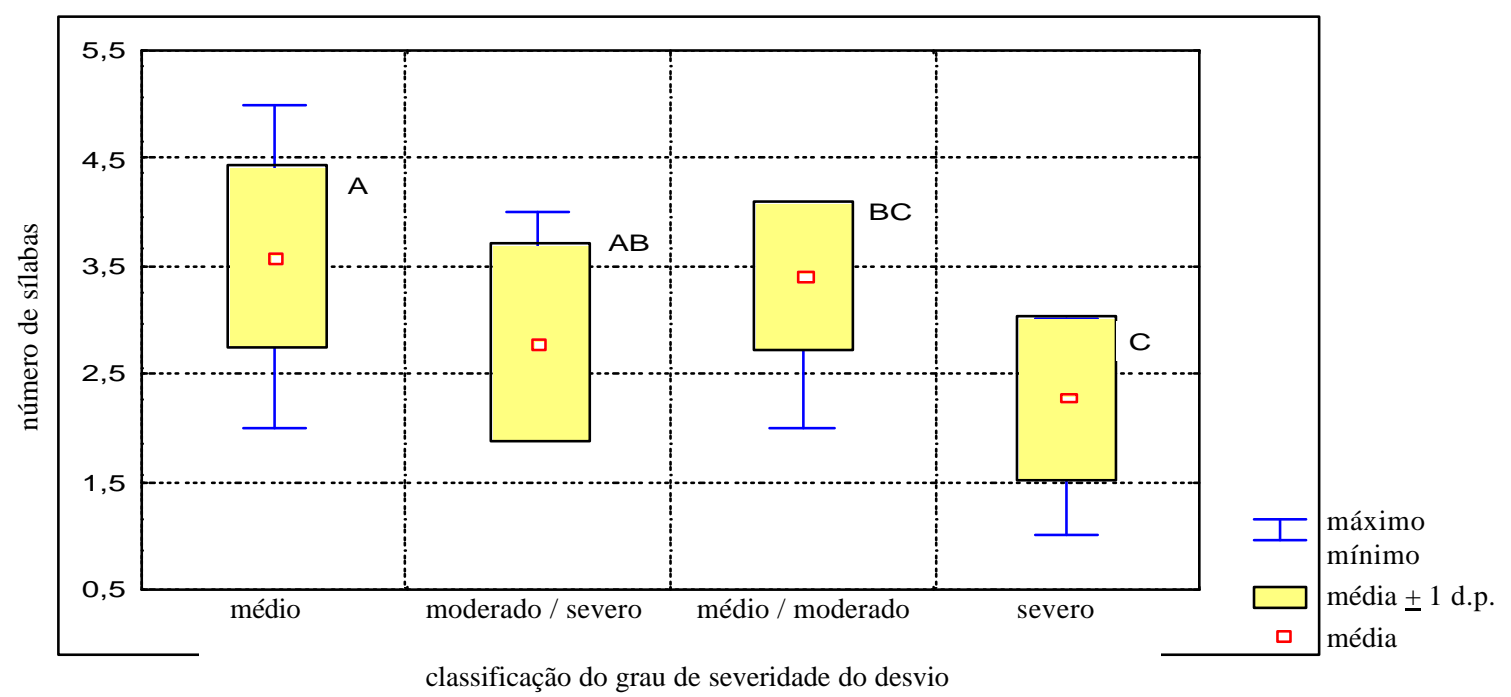

Análise: Letras diferentes é porque as médias diferem estatisticamente ( $\mathrm{p}<0,05)$ - Análise de Variância (teste de Duncan).

\section{Coments}

The results were described and analyzed, starting from the Table and Pictures presented. Based on these results, some important questions regarding the working memory and the severity degree of the phonological disorder were raised.

With the application of the statistical test of Kruskal-Wallis, in Table 1, is verified that the performance obtained in the repetition of the digit span, which is one of the tests that has been used to assess the central executor, does not present meaningful relation with the severity degree of the disorder, as can be visualized in Picture 1. These results suggest, that the performance of the central executor, compounding of working memory, may not have influence in verifying of the severity degree of the phonological disorder. This can be justified by the fact that the central executor is responsible for the information processing and for the language development.

Bull et al. (1999) refer that the central executor, compound the working memory, is related to the vocabulary acquisition. Baddeley and Hitch (1974) refer that the central executor is responsible for the processing and storage of information.

However, it should be noticed that the central executor in children with phonological disorder should be better studied through other tests, in a posterior study, to verify the existence of the relation between the central executor and the severity degree of the disorder.

In regard to the phonological memory, it is verified on Table 1 by the application of the statistical test of Kruskal-Wallis, that the performance of phonological memory, presents positive relation with the severity degree disorder, because children repeated nonsense words with the smaller number of syllables, presented more unintelligible speech. These results confirm the supposition that there is association between the phonological memory and the severity degree of the phonological disorder, as verified in Picture 2.

The phonological memory is responsible for the storage of the phonological material, by the production of the spontaneous speech, and mentally represents the phonological characteristics of the language. That is why alterations in phonological memory abilities can influence the phonological disorder in higher or lower degree. Then, the relation found in this study between the phonological memory and the severity degree deviance can be occurred due to speech abilities be more related to the phonological memory. 
These results are compatible with the ones presented by Adams and Gathercole (1995) that verified the existence of an intimate relationship between the abilities of the phonological memory and the quantity and quality of spontaneous speech produced by children. The authors conclude that the phonological memory is related to the speech production and the phoneme choice for the words production.

These findings also agree with Couture and McCauley (2000) and Bishop et. al. (1999) when refer that the alterations in the phonological memory have been associated to the phonological disorders and to the phonological aspects in specific language alterations.

It is useful to highlight with this findings that out of the different components of working memory, alteration in only one of them can occur, agreeing with Baddeley (2001), Gathercole and Pickering (2000) and Pickering et.al. (1999) when mention that the working memory can be divided into components so that the alteration can occur in one of them but not in the other.

When Picture 3 is analyzed, with Duncan Variance Analysis application, it is proved that there is a relation between the abilities of the phonological memory and the severity degree of the phonological disorder, once there was statically meaningful difference between them.

Thus, there was no statistically meaningful difference when the medium disorder was compared to the medium-moderate one. There was statically meaningful difference when medium disorder was compared to the moderate-severe one. The performance in the nonsense words repetition test in moderate-severe and severe was lower than the medium disorder. There was not statistically meaningful difference when the medium-moderate disorder was compared to the moderate-severe one.
There was statistically meaningful difference when the medium-moderate disorder was compared to the severe one. The performance in the nonsense words repetition test was lower to the medium-moderate one.

One of the forms to explain the fact that children with severe disorder repeat nonsense words with a smaller number of syllables when compared to children with medium disorder is that the former present higher alteration in abilities of phonological memory. This confirms that alterations in this component of working memory may influence the development of the speech in higher or lower degree.

Despite the inexistence of studies comparing the abilities of the working memory and the severity degree of the phonological disorder, some authors claim that there is a meaningful link between the abilities of the phonological memory and the complexity of the speech production. Adams and Gathercole (1995) refer that children with alterations in abilities of phonological memory present more mistakes in their speech production.

Regarding the words extension effect, it is noticed that the same presents relation with the severity degree of the disorder because children with severe disorder repeated nonsense words with a lower number of syllables, and children with medium disorder repeated nonsense words with a higher number of syllables. These results show that the longer the word (in letters, syllables number) the more difficult it will be for the children with the phonological disorder to store and repeat them, eliciting their alteration in the phonological memory.

These findings agree with Couture and McCauley (2000) when claim that longer words are more difficult to be repeated by children with linguistic alterations, reflecting a limited capacity of phonological memory. The children with EPD are sensible to the words extension effect. 


\section{Conclusion}

The analysis of the results shows that the performance of the phonological memory presents positive relation with the severity degree of the phonological disorder. This leads us to accept the idea that the phonological memory is related to the speech production and with the choice of the phonemes for words production.

Regarding the central executor, the results show that the performance in the digit span repetition, which has been used to assess it, may have no relation with the severity degree of the disorder. The results can be justified by the fact that the central executor is more related to the language development. However, it is suggested for a later study, a number of tests to confirm whether the central executor performance influences or not the acquisition of the severity degree of the disorder.

It is highlighted that the relation between working memory and the severity degree of the phonological disorder has been little studied in Literature. The diagnosis of alterations in working memory might have an important role in children rehabilitation with phonological disorders.

It is believed that in a Phonological Prevention program, the identification of alterations in the components of the working memory may minimize or avoid that human communication disorders occur later in people lives.

\section{Referências Bibliográficas}

ADAMS, A. M.; GATHERCOLE, S. E. Phonological working memory and speech production in preschool children. Journal of Speech and Hearing Research, v. 38, n. 2, p. 403-414, 1995.

ADAMS, A. M.; GATHERCOLE, S. E. Limitations in working memory: implications for language development. International Journal of Communication Disorders, v. 35, n. 1 , p. $95-116,2000$.

BADDELEY, A. D.; HITCH, G. J. Working memory. In: BOWER G. (Ed.). The psychology of learning and motivation. New York: Academic Press, 1974. p. 47-90.

BADDELEY, A. D. Is working memory still working? Am Psychology, v. 56, n. 11, p. 851-864, 2001.

BISHOP, D. V. M.; BISHOP, S. J.; BRIGHT, P.; JAMES, C.; DELANEY, T.; TALLAL, P. Different origin of auditory and phonological processing problems in children with language impairment: evidence from a twin study. Journal of Speech, Language, and Hearing Research, v. 42, n. 1, p. 155-168, 1999.

BOGOSSIAN, M. A. D. S.; SANTOS, M. J. Adaptação brasileira - teste Ilinóis de habilidades psicolingüísticas. Florianópolis: Tamasa, 1977.

BULL, R.; JOHNSON, R. S.; ROY, J. Exploring the roles of the visuo-spacial sketchpad and central executive in children's arithmetical skills: views from cognition and developmental neuropsychology. Developmental Neuropsychology, v. 14, n. 15, p. 421-442, 1999.

COUTURE, A. E.; McCAULEY,R. J. Phonological working memory in children with phonological imairment. Clinical Linguistic \& Phoonetics, v. 14, n. 7, p. 499-517, 2000.
FLAVELl, J. H.; MILlER, P. H.; MILLER, S. A. Desenvolvimento cognitivo. Porto Alegre: Artmed, 1999. p. 222.

GATHERCOLE, S. E.; PICKERING, S. J. Assessment of working memory in six-and seven-year-old children. Journal of Educational Psychology, v. 92, n. 2, p. 377-390, 2000.

GATHERCOLE, S.; FRANKISH, S.; PICKERING, S. E.; PEAKER, S. Influência fonotática sobre a memória de curto prazo. Journal of Experimental Psycology: Learning, Memory and Cognition, v. 25, n. 1, p. 84-95, 1999.

GONÇALVES, C. S. A interferência na memória de trabalho fonológica no desenvolvimento da linguagem. Conselho Federal de Fonoaudiologia. Revista Fonoaudiologia Brasil, v. 2, n. 1, p. 10-18, 2002.

KESSLER, T. M. Estudo da memória de trabalho em préescolares. 1997. 36 f. Dissertação (Mestrado em Distúrbios da Comunicação Humana) - Universidade Federal de São Paulo, Escola Paulista de Medicina, São Paulo.

JERONYMO, R. R.; GALERA, A. A relação entre a memória fonológica e a habilidade lingüística de crianças de 4 a 9 anos. Pró-Fono Revista de Atualização Científica, v. 12, n. 12, p. 55-60, 2000.

LAMPRECHT, R. R. Diferenças no ranqueamento de restrições com origem de diferenças na aquisição fonológica. Letras de Hoje, Porto Alegre, v. 34, n. 3, p. 65 - 82, 1999.

LINASSI, L. Z. Memória de trabalho em crianças com desvio fonológico. 2002. 87 f. Dissertação (Mestrado em Distúrbio da Cominucação Humana) - Universidade Federal de Santa Maria, Santa Maria. 
LINASSI, L.; KESKE-SOARES, M.; MOTA, H. Memória de trabalho em crianças com desvios fonológicos. PróFono Revista de Atualização Científica, v. 16, n. 1, p. 75-82, 2004.

MACBRIDE-CHANG, C.; HO, C. Developmental issues in chinese childen's character acquisition. Journal of Educational Psychology, v. 92, n. 1, p. 50-55, 2000.

OAKHILL, J.; KYLE, F. The relations between phonological: awareness and working memory. Journal Experimental Child Psycology, v. 75, n. 2, p. 152-164, 2000.

PICKERING, S. J.; GATHERCOLE, S. E.; HALL, M.; LIOYD, S. Development of memory for pattern and path: further evidence for the fractionation of visuo-spatial short term memory. Quatherly Journal of Experimental Psycology, v. 48, n. 2, p. 98-107, 1999.

SANTOS, M. R.; SIQUEIRA, M. Consciência fonológica e memória. Revista Fono Atual, n. 20, p. 48-53, $2^{\circ}$ trimestre, jun. 2002.

SHRIBERG, L. D.; KWIATKOWSKI, J. Phonological disorders I: a diagnostic classification system. Journal of Speech and Hearing Disorders, v. 47, n. 3, p. 226-241, 1982.

SIEGEL, S. Estatística não paramétrica. São Paulo: McGrawMill do Brasil, 1975. 350 p.

STERNBERG, R. J. Psicologia cognitiva. Porto Alegre: Artes Médicas, 2000.

YAVAS, M.; HERNANDORENA, C. L. M.; LAMPRECHT, R. R. Avaliação fonológica da criança: reeducação e terapia. Porto Alegre: Artes Médicas, 1991. 